\title{
Phospholipases and their industrial applications
}

\author{
L. De Maria • J. Vind • K. M. Oxenbøll • A. Svendsen • \\ S. Patkar
}

Published online: 5 May 2007

(C) Springer-Verlag 2007

\section{Erratum to: Appl Microbiol Biotechnol DOI: $10.1007 / \mathrm{s} 00253-006-0775-x$}

At your direction, Diversa worked with the authors of the mini-review and agreed on language for a corrigendum as follows:

In the recent review article by De Maria et al., "Phospholipases and their industrial applications" (2007) Appl. Microbiol Biotechnol. 74: 290-300, the phospholipase $\mathrm{C}$ in the commercial product Purifine ${ }^{\mathrm{TM}}$ was mentioned. The phospholipase $\mathrm{C}$ in Purifine ${ }^{\mathrm{TM}}$ is closely related to the well-characterized phospholipase $\mathrm{C}$ from Bacillus cereus and the enzyme is expressed in Pichia pastoris (Ciofalo et al., 2006).

Ciofalo V., Barton, N., Kreps, J., Coats, I., Shanahan, D. (2006). Safety evaluation of a lipase enzyme preparation, expressed in Pichia pastoris, intended for use in the degumming of edible vegetable oil. Regul. Toxicol. Pharmacol. 45: 1-8.

The online version of the original article can be found at http://dx.doi. org/10.1007/s00253-006-0775-x.

L. De Maria $\cdot$ J. Vind · K. M. Oxenbøll · A. Svendsen •

S. Patkar $(\square)$

Novozymes A/S,

Krogshoejvej 36,

2880 Bagsvaerd, Denmark

e-mail: sap@novozymes.com 